DOI https://doi.org/10.30525/978-9934-26-111-4-19

\title{
ЕКОЛОГО-БІОЛОГІЧНА І ЦЕНОТИЧНА ХАРАКТЕРИСТИКА ТА ГЕОГРАФІЧНІ ОСОБЛИВОСТІ ЛІКАРСЬКОЇ РОСЛИНИ GERANIUM PHAEUM L. У ФЛОРІ УКРАЇНИ
}

\author{
Панчук О. В. \\ кандидат біологічних наук, \\ доиент кафедри біологіі \\ Національний медччний університет імені О. О. Богомольияя \\ Романенко О. В. \\ доктор біологічних наук, професор, \\ завідувач кафедри біології \\ Національний медичний університет імені О. О. Богомольияя \\ м. Київ, Україна
}

Україна багата на природні ресурси цінних видів рослин, серед яких відповідне місце займають лікарські. Проте, зважаючи на обмежену ресурсну базу частини 3 них, особливої актуальності набувають виявлення їх сировинних резервів, розробка наукового обгрунтування їх невиснажливого використання, виходячи 3 оцінки їх ресурсів. Відповідно, необхідним є дослідження закономірностей поширення рослини, яка потенційно може знайти застосування в медичній галузі, вивчення іiї запасів, розробка плану та режиму експлуатації природних ресурсів цієї рослини, а також їх відтворення. За умови обмеженості природних запасів лікарської рослини, заслуговує на увагу вивчення біологічних особливостей виду, у тому числі морфологічних, а також екологічних умов зростання та ценотичної приуроченості такої рослини, що в цілому є важливим для визначення можливості iii використання у подальшому за згаданим призначенням, а також інтродукції.

Представники родини Геранієвих (Geraniaceae) відомі своїми лікувальними властивостями, зокрема, антисептичними, протизапальними, кровоспинними, протимікробними $[5,7,8]$. Звернемо увагу на один $з$ видів цієї родини, а саме на Geranium phaeum L. Його представники виявляють антибактеріальні властивості, характеризується наявністю фенолкарбонових кислот та їх похідних, дубильних речовин, катехінів, лейкоантоціанідинів, флавоноїдів, антоціанінів [9]. 
Вид G. phaeum L. поширений на території Середньої та Західної Європі, на півдні Скандинавії, в Середземномор'ї. Його представники зростають у світлих лісах, між чагарниками, на луках. Трапляються вони й на заході України, від Волинської області до лісового поясу Карпат, на території Закарпатської, Львівської, Волинської, Івано-Франківської, Тернопільської областей. Згадану рослину можна зустріти часто на Поділлі, зрідка в Житомирській, Київській, Чернігівській та Сумській областях.

G. phaeum L. є трав'янистим полікарпиком, гемікриптофітом, коротко-кореневищною рослиною з напіврозетковим типом надземних пагонів. В рослини міцне, горизонтальне кореневище; стебло прямостояче, негусто улиснене, вгорі розгалужене. Воно, як і черешки листків, квітконоси, квітконіжки та чашолистики, вкрите довгими відстовбурченими волосками; а у верхній частині (до квітоніжок) характеризується як коротко залозисто-пухнасте. В рослини листки зверху вкриті довгими притиснутими волосками, а зісподу листки голі або коротковолосисті. Прикориневі листки мають довгі, 12-20 см завдовжки, черешки; пластинку в обрисі ниркоподібно-округлу (6-7 см), пальчасто-семи-роздільну. В рослини прилистки яйцевидноланцетні, загострені. Вони червонуваті й вкриті білими волосками. В рослини квітконоси заввишки 3-8 см, двоквіткові, а квітконіжки завдовжки 3-4 см. Перед цвітінням і при плодах квітконоси нахилені в один бік. Чашолистики в рослини еліптичні, завдовжки 7-8 мм, а при плодах досягають довжини 9-11 мм. Пелюстки в рослини завдовжки 11-13 мм, по краю вони зарубчасто-зубчасті, темнофіолетові, розпростерті. Частки плоду у верхній частині впоперек зморшкуваті, а у нижній є довговолосистими; придатки плоду короткопухнасті $[3,4]$.

Екологічні особливості виду визначаються за провідними едафічними та кліматичними чинниками з використанням методу фітоіндикації $[1,2]$. За відношенням до водного режиму G. phaeum L. $€$ мезофітом. Представники виду зростають на свіжих лісо-лучних екотопах 3 повним промочуванням кореневмісного шару грунту грунтовими водами. За відношенням до вмісту карбонатів в грунті $G$. phaeum L. $\epsilon$ гемікарбонатофобом, рослиною, яка уникає карбонатних субстратів. Вона поширена на підзолистих та лучних глеєвих грунтах. Зважаючи на те, що вважливим складовим елементом грунту є азот, звернемо увагу на залежність розвитку G. phaeum L. від його наявності. Ця рослина $\epsilon$ нітрофілом, який зростає на відносно забезпечених мінеральним азотом грунтах. Виходячи з залежності кислотного режиму грунту від його хімічного складу і грунтових порід, відзначимо, що G. phaeum L. $\epsilon$ субацидофілом, рослиною, яка зростає на слабокислих грунтах. 
За відношенням до узагальненого сольового режиму грунту вона належить до семіевтрофної екогрупи. Характерним для ï представників $\epsilon$ зростання на багатих на солі грунтах.

Вид G. phaeum L. належить до сціогеліофітів, сильвантів. За участю в ценозах він відноситься до асектаторів (такі рослини відіграють відносно незначну роль у фітоценозі і мають проективне покриття до $20 \%$ ), а за широтою екологічної амплітуди він належить до геміевритопів. Його можна зустріти в тінистих широколистяних лісах, a також в чагарникових заростях. Він зазвичай трапляється в угрупованнях мезофільних широколистяних лісів України порядку Fagetalia sylvaticae (в союзах Alnion incanae, Carpinion betuli та Fagion sylvaticae) у складі класу Querco-Fagetea Br.-B1. [6].

Вид G. phaeum L. зустрічається також в напівпорушених місцезростаннях на сірих лісових та перегнійно-карбонатних грунтах i на опідзолених чорноземах парків і лісопарків міст в західній частині України. Рослинні угруповання за участі рослин названого виду найчастіше представлені похідними ценозами старих парків, створеними на місці корінних лісових ценозів, а при значних рекреаційних навантаженнях тяжіють до угруповання класу Robinietea. При цьому у складі деревостану переважають автохтонні едифікатори, проте водночас доволі широко можуть бути представленими й інтродуковані породи. В згаданих умовах у підліску часто домінує Sambucus nigra, у трав'яному покриві виділяється значна частка тих видів, що характерні для класу Querco-Fagetea, проте домінуючими бувають й види з групи так званих «лісових бур'янів», трапляється багато рудералів. Наведене вище ілюструє здатність багаторічних мезофітних сціофітних гераней флори України поширюватися на злегка порушених нітрифікованих місцезростаннях.

Вид G. phaeum L. є представником сагетального флороценотичного комплексу, притаманний для тіньових мезофітних широколистяних лісів середньоєвропейського типу, виявляє здатність до розвитку в порушених лісових угрупованнях за збереження їх ценотичної структури.

Вид G. phaeum L. хоча потенційно й володіє корисними для медицини властивостями, проте має лише фрагментарне поширення в західних регіонах України та окремі локалізації на Поділлі й зрідка трапляється, наприклад, в Київській та Житомирській областях, тому можна говорити про обмеженість його сировинних ресурсів для ведення промислової заготівлі. Разом з тим названий вид може бути рекомендованим для інтродукції. 


\section{Література:}

1. Дідух Я. П., Плюта П. Г. Фітоіндикація екологічних факторів. Київ: Наукова думка, 1994. 280 с.

2. Екофлора України / Я. П. Дідух, П. Г. Плюта, В.В. Протопопова та ін. - К.: Фітосоціоцентр, Т. 1. 2000. 284 с.

3. Касянчук О.В. Біоморфологічний аналіз видів родини Geraniaceae флори України //Матеріали міжнародної науковопрактичної конференції «Біорізноманіття: теорія, практика та методичні аспекти вивчення у загальноосвітній та вищій школі» (Полтава, 11-12 лютого 2010 р.). Полтава, 2010. С. 89-90.

4. Флора УРСР: у 12 т. /ред. рада: Д.К. Зеров (гол.) та ін.; Ін-т ботаніки академії наук УРСР Київ: Видавництво академії наук УРСР, 1955. T. $7657 \mathrm{c}$.

5. Касянчук О.В. Впровадження у навчальний процес відомостей про поширення та застосування лікарських рослин родини Geraniaceae Juss. флори України //Науковий часопис Національного педагогічного університету імені М.П. Драгоманова. Серія № 5. Педагогічні науки: реалії та перспективи. Випуск 22: збірник наукових праць / за ред. В. П. Сергієнка. Київ: Вид-во НПУ імені М. П. Драгоманова, 2010. C. 149-152.

6. Онищенко В. А. Закономірності поширення лісових угруповань природного заповідника «Медобори» / В.А. Онищенко // Український фітоценологічний збірник. 1998. Сер. С, №1 (10). С. 93-99.

7. Панчук О.В., Романенко О.В. Еколого-ценотичні особливості лікарської рослини Geranium sibiricum L. у флорі України // PLANTA+. Досягнення і перспективи: матеріали міжнародної науково-практичної конференції, присвяченої пам'яті доктора хімічних наук, професора Ніни Павлівни Максютіної (до 95-річчя від дня народження) (Київ, 20-21 лютого 2020 р.). - Київ: ПАЛИВОДА А.В., 2020. С. 323-326.

8. Панчук О.В., Романенко О.В. Еколого-ценотична характеристика та географічні особливості лікарської рослини Geranium pratense L. // PLANTA+. НАУКА, ПРАКТИКА ТА ОСВITA: матеріали Міжнародної науково-практичної конференції (Київ, 19 лютого 2021 р.). Електрон. дані. Київ: ПАЛИВОДА А. В., 2021. С. 510-514.

9. Мінарченко В.М. Лікарські судинні рослини України (медичне та ресурне значення). Київ: Фітосоціоцентр, 2005. 323 с. 